\title{
A case of severe frost damage prior to budbreak in young conifers in Northeastern Ontario: Consequence of climate change?
}

\author{
by Rongzhou Man ${ }^{1,2}$, Gordon J. Kayahara ${ }^{3}$, Qing-Lai Dang ${ }^{4}$ and James A. Rice ${ }^{1}$
}

\begin{abstract}
In spring 2007, young planted and natural conifers suffered extensive needle and bud injury near Hearst and Kapuskasing in northeastern Ontario. Damage was observed on all species of conifers up to 20 years old and $8 \mathrm{~m}$ in height. Taller trees, especially those in the overstory, and young understory trees protected by a closed canopy had less damage. The damage was caused by earlier than normal loss of cold hardiness followed by late spring frosts according to damage observations, weather station data, and calculated thermal time requirements for budbreak and cold hardiness of conifers. During May 19 to 21, 2007, minimum temperatures were recorded between $-8^{\circ} \mathrm{C}$ and $-9^{\circ} \mathrm{C}$, and before this period, temperatures were warm enough to induce early dehardening and loss of trees' cold hardiness. According to the historical weather data for Kapuskasing, estimated budbreak time has become earlier since 1918 and freezing temperatures during budbreak and shoot elongation (between growing degree days 100 and June 15) have become more frequent since 1980. If the trend towards earlier budbreak is due to climate change, then the type of frost damage we observed in northeastern Ontario in 2007 could become more common. We discuss implications of such events and suggest research needed to understand the risk of frost damage with climatic warming and to reduce damage.
\end{abstract}

Key words: conifer frost damage, mature needle and bud (or needle/bud) mortality, early dehardening and budbreak (or dehardening/budbreak), climatic warming

\section{RÉSUMÉ}

Au printemps 2007, de jeunes conifères plantés et naturels ont subi des dommages importants aux aiguilles et aux bourgeons dans la région de Hearst et de Kapuskasing dans le nord-est de l'Ontario. Les dégâts ont été observés sur toutes les espèces de conifères âgées de moins de 20 ans et atteignant $8 \mathrm{~m}$ de hauteur. Les arbres plus grands, notamment ceux dominant le couvert, ainsi que les jeunes arbres en sous-étage protégés par la fermeture du couvert ont subi moins de dégâts. Les dégâts ont été causés par une perte plus hâtive que normale de la résistance au froid suivie de gels printaniers tardifs selon les observations des dégâts, les données des stations météorologiques et les besoins en degrés-jours calculés pour provoquer le débourrement et lendurcissement au froid chez les conifères. Du 19 au 21 mai 2007, les températures minimales enregistrées ont atteint entre $-8^{\circ} \mathrm{C}$ et $-9^{\circ} \mathrm{C}$ et, avant cette période, les températures avaient été suffisamment chaudes pour amorcer un désendurcissement hâtif et une cessation des mécanismes de résistance au froid. Selon l'historique des données météorologiques de Kapuskasing, la période du débourrement est de plus en plus hâtive depuis 1918 et les gels tardifs au cours du débourrement et de la croissance de la pousse terminale (entre le degré-jour 100 et le 15 juin) sont de plus en fréquents depuis 1980. Si la tendance vers un débourrement plus hâtif est la conséquence des changements climatiques, alors ce type de dégâts par le gel que nous avons observé dans le nord-est de l'Ontario en 2007 pourrait devenir plus fréquent. Nous discutons des implications de tels événements et identifions les recherches requises pour comprendre les risques associés aux dégâts par le gel en fonction des changements climatiques et pour réduire les dégâts.

Mots clés : dégâts par le gel sur les conifères, mortalité des aiguilles âgées et des bourgeons (ou aiguilles/bourgeons), désendurcissement hâtif et débourrement (ou désendurcissement/débourrement), réchauffement climatique

\footnotetext{
${ }^{1}$ Ontario Ministry of Natural Resources, Ontario Forest Research Institute, 1235 Queen Street East, Sault Ste. Marie, Ontario P6A 2E5.

${ }^{2}$ Corresponding author. E-mail: rongzhou.man@ontario.ca

${ }^{3}$ Ontario Ministry of Natural Resources, Northeast Science and Information Section, Hwy 101 East, P.O. Bag 3020, South Porcupine, Ontario P0N $1 \mathrm{H} 0$.

${ }^{4}$ Faculty of Forestry and the Forest Environment, Lakehead University, Thunder Bay, Ontario P7B 5E1.
} 


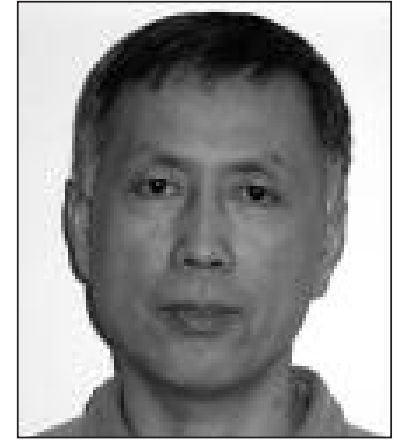

Rongzhou Man

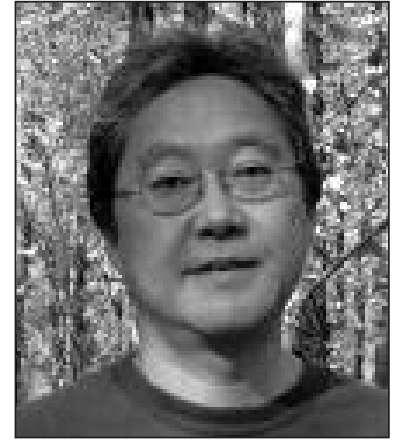

Gordon J. Kayahara

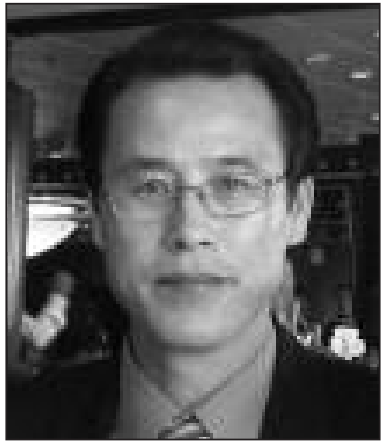

Qing-Lai Dang

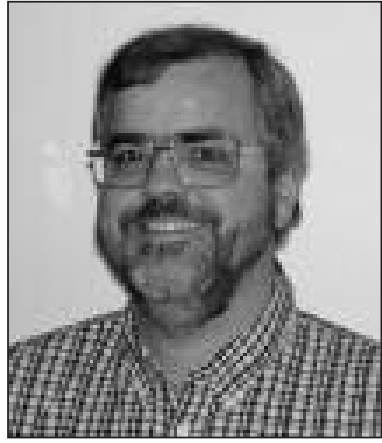

James $A$. Rice

\section{Introduction}

In late May of 2007, young plantations of black spruce (Picea mariana) (Fig. 1), white spruce (Picea glauca), and jack pine (Pinus banksiana) near Kapuskasing and Hearst in northeastern Ontario (Fig. 2) suffered severe needle mortality prior to budbreak. Damage also occurred to naturally regenerated black spruce, jack pine, balsam fir (Abies balsamea), eastern white cedar (Thuja occidentalis), and larch (Larix laricina) (Fig. 3). Local forest managers immediately raised concerns about the event, the scale of which has not been observed previously. Could the damage cause extensive tree death and affect a range of values from wildlife habitat to wood supply? Was this event merely random or related to global climate change?

In July 2007, the Forest Health Monitoring Program (a partnership between the Canadian Forest Service and Ontario Ministry of Natural Resources' (OMNR) Forest Health and Silvicultural Section) mapped the affected area through an aerial survey (Fig. 2). In mid-August 2007, staff with Tembec, Hearst Forest Management Inc., and the Ontario Ministry of Natural Resources conducted a field reconnaissance. The group believed the damage was weatherrelated and found that the aerial survey vastly underestimated the extent of damage most likely due to the shedding of dead needles and flushing of conifers and hardwoods after needle mortality but before the survey. Needle mortality was reported both west and south of the mapped area (Fig. 2). The affected forest covered several thousand hectares, which were dominated by planted black spruce.

The group identified several weather-related scenarios as possible causes of the damage: 1) needles experienced moisture stress in the spring due to damage to fine roots near the soil surface, caused by low snow cover and therefore cold soil temperature during the 2006-07 winter; 2) needles were desiccated during the late winter or early spring because air temperatures were well above freezing points but water supply was restricted due to cold or frozen soil; and 3) needles were damaged by late spring frost due to unseasonably warm temperatures in late April and early to mid-May 2007, which caused trees to deharden early and subsequently become vulnerable to severe freezing temperatures from May 19 to 21 .

During the field reconnaissance, 2 actions were proposed: 1) improve documentation of the extent and nature of the damage by establishing permanent sample plots in affected stands to assess short-term mortality and long-term growth responses, and 2) investigate the most likely cause(s) by examining weather data. This paper focuses on weather conditions in the winter and spring of 2006-07, and trends in long-term weather records.

\section{Description of Affected Stands}

Affected stands were found in the northern clay forest section of the boreal forest region (Rowe 1972). Lowland sites are dominated by stands of black spruce with larch and cedar occasionally found. On upland sites where drainage is better, mixedwood stands containing trembling aspen, balsam fir, black spruce, white spruce, and occasional jack pine are common (Rowe 1972).

Damage was first observed in late May 2007 when mature needles began turning red prior to budbreak (Fig. 4). Needle reddening was widely evident by mid-June (Fig. 1). By midAugust, the only live needles on many affected trees were those from 2007, as the older needles had died and then shed. However, in a zone up to $20 \mathrm{~cm}$ above the ground, small seedlings and lower branches of older trees were not affected. Needle damage appeared to be less in taller trees and the upper crown of affected trees; needles in mature trees in the overstory were not affected. Understory conifers had less needle damage than open-growing conifers, especially where the overstory was dominated by conifers.

Damage was first noticed on planted black spruce and later on all natural and planted conifer trees of all species with tree ages up to 20 years old and heights up to $8 \mathrm{~m}$ tall. Affected trees were found in stands on both upland and lowland sites with soils of all texture classes from organic to sand to clay. All sides of tree crowns were affected. Needle mortality on affected trees ranged from $70 \%$ to $100 \%$. In plantations aged 1 to 5 years, trees often had $100 \%$ needle mortality.

Buds were generally less affected than needles. In black spruce about $20 \%$ to $30 \%$ of buds, particularly those in the lower crown, were injured and failed to flush. As with needle damage, bud failure also decreased with tree height. In larch, however, reflushing occurred after the first flushing shoots were killed (Fig. 3). White spruce and balsam fir often had $90 \%$ or higher needle mortality and bud failure.

\section{Evaluation of Weather-Related Hypotheses for Causes of the Damage during Winter 2006-07} Root-freezing damage

Snow cover and organic materials on the forest floor insulate the soil from the air and slow heat loss from the ground. During the winter of 2006-07 below-average snow cover resulted 


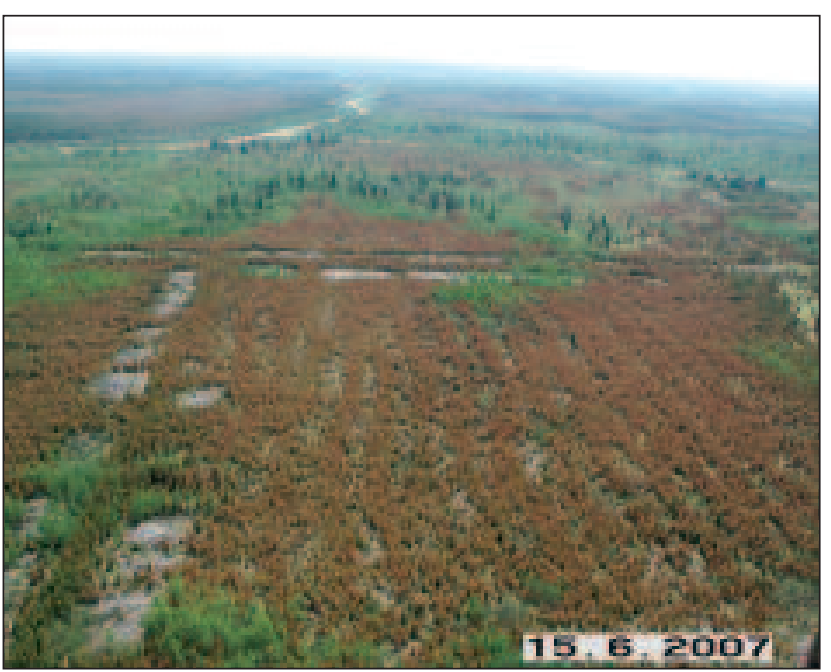

Fig. 1. An aerial view of damaged black spruce plantations in midJune, shortly after budbreak.

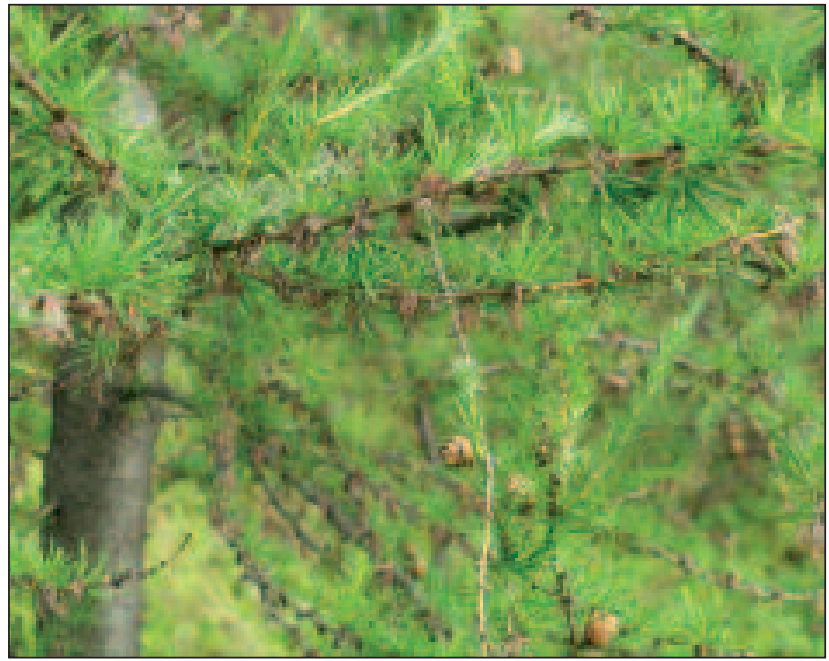

Fig. 3. A tamarack with needle mortality (current growth) in midAugust.

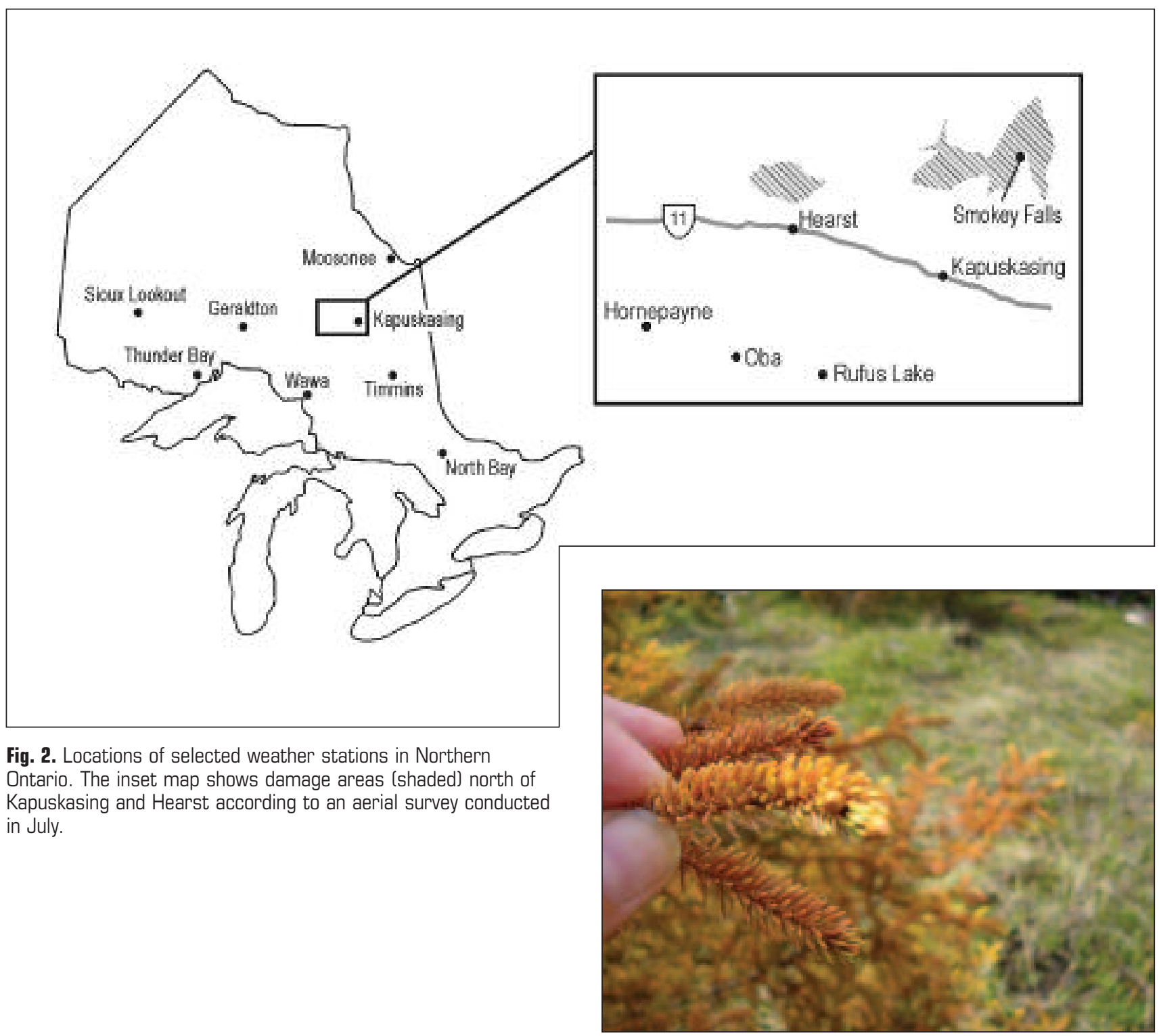

Fig. 4. Black spruce twigs in late May 10 days after the freezing nights. 
Table 1. Snow depth (cm) and daily mean soil temperatures $\left({ }^{\circ} \mathrm{C}\right.$ ) at Kapuskasing from November to May

\begin{tabular}{|c|c|c|c|c|c|c|c|}
\hline Observation & Nov. & Dec. & Jan. & Feb. & Mar. & Apr. & May \\
\hline & \multicolumn{7}{|c|}{ 1971-2000 average } \\
\hline Average snow depth & 0 & 21 & 38 & 50 & 49 & 20 & 0 \\
\hline Month-end snow depth & 12 & 30 & 37 & 50 & 40 & 1 & 0 \\
\hline Temperature at $5 \mathrm{~cm}$ & 0.8 & -1.0 & -1.4 & -1.3 & -1.0 & 0.5 & 8.4 \\
\hline Temperature at $10 \mathrm{~cm}$ & 0.9 & -1.0 & -1.6 & -1.6 & -1.4 & -0.3 & 6.9 \\
\hline Temperature at $20 \mathrm{~cm}$ & 1.9 & 0.3 & -0.4 & -0.5 & -0.4 & 0.5 & 7.3 \\
\hline
\end{tabular}

2006-2007 winter

\begin{tabular}{lcccccc} 
& & & 10 & 13 & 12 & 7 \\
Average snow depth & 0 & 4 & 13 & 11 & 0 & 0 \\
Month-end snow depth & 0 & -1.2 & -1.8 & -2.8 & -1.6 & 0 \\
Temperature at $5 \mathrm{~cm}$ & 0.5 & -0.9 & -1.5 & -2.5 & -1.6 & 1.1 \\
Temperature at $10 \mathrm{~cm}$ & 0.8 & 0 & -0.7 & -1.7 & -1.3 & 0.4 \\
Temperature at $20 \mathrm{~cm}$ & 1.7 & & & 8.6 \\
\hline
\end{tabular}

Table 2. Deviation of the mean monthly temperatures $\left({ }^{\circ} \mathrm{C}\right.$ ) for winter of 2006-07 from the 1971-2000 long-term normals for selected weather stations in Northern Ontario

\begin{tabular}{|c|c|c|c|c|c|c|c|}
\hline \multirow[b]{2}{*}{ Weather station } & \multicolumn{2}{|c|}{2006} & \multicolumn{5}{|c|}{2007} \\
\hline & Nov. & Dec. & Jan. & Feb. & Mar. & Apr. & May \\
\hline 1. Moosonee & +2.3 & +7.5 & +5.1 & -2.7 & +0.6 & +0.6 & +0.9 \\
\hline 2. Sioux Lookout & +2.4 & +6.0 & +3.5 & -4.3 & +1.4 & -0.3 & +1.4 \\
\hline 3. Geraldton & +3.4 & +6.9 & +3.7 & -4.7 & +1.4 & +0.1 & +1.3 \\
\hline 4. Kapuskasing & +2.4 & +6.5 & +3.7 & -5.1 & +0.8 & -0.2 & +0.8 \\
\hline 5. Timmins & +2.9 & +6.7 & +4.2 & -4.2 & +1.3 & +0.4 & +1.7 \\
\hline 6. Thunder Bay & +3.0 & +5.5 & +3.3 & -3.0 & +2.1 & -0.7 & +0.4 \\
\hline 7. Wawa & +3.0 & +5.4 & +3.6 & -3.8 & +1.2 & -0.2 & +1.3 \\
\hline 8. North Bay & +2.8 & +5.3 & +2.5 & -3.5 & +0.5 & +0.5 & +1.2 \\
\hline
\end{tabular}

in soil temperatures that were colder from November to March, but warmer in April and May than those of the 30year average from 1971 to 2000 (Table 1). The lowest soil temperatures of 2006-07 winter occurred in February, a colder than usual month at Kapuskasing (Table 2); the daily soil temperatures in this month, however, did not drop below $-4.0^{\circ} \mathrm{C}$ (Fig. 5), well above the level that could damage root systems of hardened boreal conifers (Colombo et al. 1995, Bigras and Margolis 1997). The colder-than-average February, while conifers were probably still very hardy, was observed across much of Northern Ontario (Table 2), yet exceptional needle damage was limited to Hearst and Kapuskasing areas of northeastern Ontario.

\section{Winter desiccation (winter drying]}

Winter desiccation occurs when conifer needles are exposed to above-freezing temperatures during winter while the soil is frozen (Berg and Chapin 1994). Conifer needles usually survive winter desiccation due to a combination of tolerance to drying (Herrick and Friedland 1991) and water stored in roots and stems and possible water uptake in mild days (Boyce and Lucero 1999). However, in extreme cases, the needles can desiccate severely, resulting in damage. The damage may occur from gradual drying over a prolonged period or after a short but intense period of drying, often exacerbated by strong winds, bright sun, and above-freezing air tempera- tures while the soil is frozen (Herrick and Friedland 1990, Berg and Chapin 1994). Severe needle damage from winter desiccation has been casually noted on newly planted seedlings (Krasowski et al. 1995) or over-wintered container seedlings (Colombo ${ }^{5}$, unpublished observations) that have restricted root access to water. Such damage is rarely found on well-established trees. The red spruce winter injury at high elevations, thought to be winter desiccation-related from early observations (Curry and Church 1952, Herrick and Friedland 1991, Hadley et al. 1991), was actually more related to freezing (Peart et al. 1991, Perkins and Adams 1995, Lazarus et al. 2004, 2006).

The temperature data at Kapuskasing and damage observations did not support winter desiccation being the main cause of damage. The daily mean temperatures were only occasionally a few degrees above freezing in the warmer months of December and January 2006-07, when the soil was nearly frozen (Fig. 1). In addition, the facts that needle mortality decreased as tree height increased and that level of needle damage did not differ among tree crown of different directions were not consistent with typical winter desiccation damage (Peart et al. 1991).

${ }^{5}$ Stephen J. Colombo, Environmental Stress Research Scientist, Ontario Forest Research Institute, 1235 Queen Street East, Sault Ste. Marie, Ontario. 


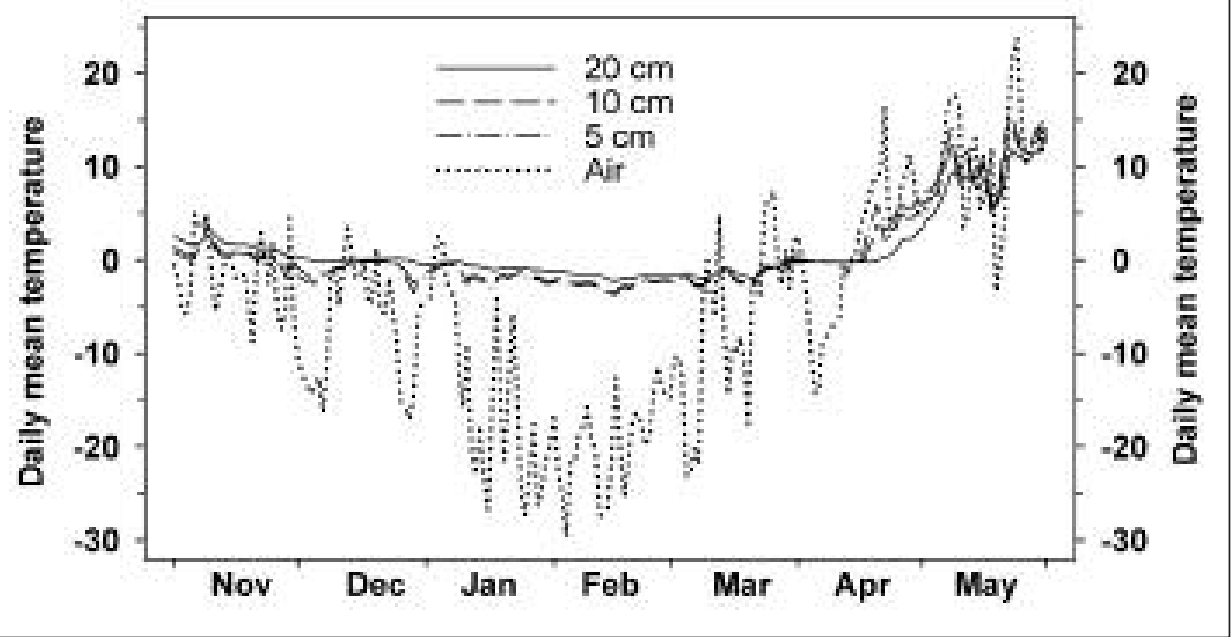

Fig. 5. Mean daily air and soil (at depths of 5,10 , and $20 \mathrm{~cm}$ ) temperatures at Kapuskasing during 2006-07 winter.

The less-than-average snow depth during winter 2006-07 could have allowed soil to be colder than normal but to warm earlier and more quickly in spring (Table 1). Shallower snow cover combined with the slightly warmer spring from March to May (Table 2) might have actually reduced desiccation damage resulting from the high transpirational demand and cold soil in late April and May. In fact, soil temperatures in May at Kapuskasing (Fig. 5) were generally well above the threshold levels that could restrict conifer water absorption (Kaufmann 1975, Running and Reid 1980, Teskey et al. 1984, Man and Lieffers 1997).

\section{Late spring frost}

Freezing temperatures after dehardening in the spring, in combination with warm post-freeze temperatures and strong radiation, can cause the type of damage observed near Hearst and Kapuskasing. During early spring, most trees in cold and temperate climates are in a state of shoot dormancy imposed by cold weather, called rest (Saxe et al. 2001). Trees at rest resume growth (and thus lose cold hardiness) in direct response to warming temperatures (Colombo 1998, Saxe et al. 2001). The date of budbreak and loss of cold hardiness for resting trees can be predicted based on the accumulation of temperatures above a threshold (or base, usually $5^{\circ} \mathrm{C}$ ) in the spring, termed growing degree days (GDD) (Sarvas 1972, Colombo 1998). In Kapuskasing during April and May 2007, the accumulation of GDD was about 1 week earlier than the 1981 to 2007 average, a period that was also close to a week earlier in cumulative GDD from the previous periods (Table 3 ). Thus, we concluded that an earlier-thannormal loss of cold hardiness followed by extreme cold nights was likely the cause of the observed damage.

On May 19 to 21,2007 , temperatures fell below $-8^{\circ} \mathrm{C}$ in the affected areas (Fig. 6; fire weather data collected by OMNR).

Table 3. Incidence of freezing temperatures (years with 1 or more freezing nights and average freezing nights per year) and average dates of critical cumulative growing degree days (GDD) at Kapuskasing from 1918 to 2007 . Critical freezing temperatures$0^{\circ} \mathrm{C},-2.5^{\circ} \mathrm{C},-4^{\circ} \mathrm{C},-6^{\circ} \mathrm{C}$, and $-8^{\circ} \mathrm{C}$-were chosen according to Bigras and Hébert (1996) and Colombo (1998). The threshold values 100 and 160 represent thermal time requirements of early and late flushing conifers.

\begin{tabular}{|c|c|c|c|c|c|c|}
\hline \multirow{3}{*}{$\begin{array}{l}\text { Temperature } \\
\text { threshold }\end{array}$} & \multicolumn{2}{|c|}{ 1981-2007 (27 years) } & \multicolumn{2}{|c|}{ 1951-1980 (30 years) } & \multicolumn{2}{|c|}{$1918-1950$ (33 years) } \\
\hline & Years & Nights/year & Years & Nights/year & Years & Nights/year \\
\hline & \multicolumn{6}{|c|}{ Time period from May 16 to June 15} \\
\hline$\leq 0^{\circ} \mathrm{C}$ & 27 & 6.78 & 30 & 6.00 & 33 & 7.37 \\
\hline$\leq-2.5^{\circ} \mathrm{C}$ & 23 & 2.33 & 23 & 2.03 & 24 & 2.73 \\
\hline$\leq-4^{\circ} \mathrm{C}$ & 14 & 1.10 & 12 & 0.80 & 14 & 1.12 \\
\hline$\leq-6^{\circ} \mathrm{C}$ & 7 & 0.37 & 5 & 0.17 & 8 & 0.45 \\
\hline \multirow[t]{2}{*}{$\leq-8^{\circ} \mathrm{C}$} & 2 & 0.11 & 2 & 0.03 & 3 & 0.12 \\
\hline & \multicolumn{6}{|c|}{ Time period from GDD $\geq 100$ to June 15} \\
\hline$\leq 0^{\circ} \mathrm{C}$ & 26 & 5.00 & 19 & 3.13 & 20 & 3.61 \\
\hline$\leq-2.5^{\circ} \mathrm{C}$ & 16 & 1.44 & 9 & 0.63 & 11 & 1.03 \\
\hline$\leq-4^{\circ} \mathrm{C}$ & 8 & 0.78 & 3 & 0.10 & 3 & 0.30 \\
\hline$\leq-6^{\circ} \mathrm{C}$ & 2 & 0.19 & 2 & 0.07 & 2 & 0.09 \\
\hline \multirow[t]{2}{*}{$\leq-8^{\circ} \mathrm{C}$} & 1 & 0.04 & 0 & 0.00 & 0 & 0.00 \\
\hline & \multicolumn{6}{|c|}{ Mean Julian days for critical cumulative GDDs } \\
\hline GDD value & Average & 2007 & Average & & Average & \\
\hline$\geq 100$ & $141^{\circ}$ & 134 & 144 & - & $146^{\circ}$ & - \\
\hline$\geq 160$ & 150 & 145 & 153 & - & 155 & - \\
\hline
\end{tabular}


This cold spell was preceded and followed by days with daily maximum temperatures up to $25^{\circ} \mathrm{C}$ to $30^{\circ} \mathrm{C}$ (Fig. 6). A $5.8-\mathrm{cm}$ snowfall during the cold spell (Environment Canada weather data at Kapuskasing) could have protected foliage close to the ground from freezing damage (Van Der Kamp and Worrall 1990). This freezing occurred when the cumulative GDD had reached 110, a condition not found in areas of Northern Ontario where no conifer damage was found (Fig. 7).

In Northern Ontario, white spruce need an average of 91.1 GDD (ranging from 67 to 114) and black spruce need an average of 150.0 GDD (ranging from 127 to 190) to meet their thermal time requirements for bud flushing (O'Reilly and Parker 1982). At Kapuskasing it generally takes 7 to 10 days for cumulative GDD to increase from 90 to 150, during midMay to early June. Both thermal time requirements for budbreak and field observations suggest that black spruce had not broken buds when freezing occurred in May 2007 (Fig. 4). Most black spruce buds were not damaged (Fig. 4) and con- tinued to develop normally. Jack pine buds can break a few days earlier than those in black spruce (Kim et al. 1997), while larch, balsam fir and white spruce can break buds as much as 2 weeks earlier than black spruce (Glerum 1973, Lieffers and Rothwell 1987, Sims et al. 1990). We did not notice damage on elongating shoots of conifers (except larch, Fig. 3), although white spruce and balsam fir had greater needle and bud mortality than black spruce and jack pine did, likely due to being more dehardened and closer to budbreak.

Conifers generally lose their cold hardiness quickly as temperatures increase in the spring (Bigras and D'Aoust 1993) until the minimum cold hardiness of shoots in the range $-3^{\circ} \mathrm{C}$ to $-5^{\circ} \mathrm{C}$ is reached at or after budbreak (Glerum 1973). Therefore, conifers near budbreak are susceptible to freezing damage. Bigras and Hébert (1996) showed that black spruce exposed $-8^{\circ} \mathrm{C}$ to $-10^{\circ} \mathrm{C}$ suffered only minor needle loss at the beginning of budbreak but experienced substantial needle and seedling mortality when freezing happened after termi-

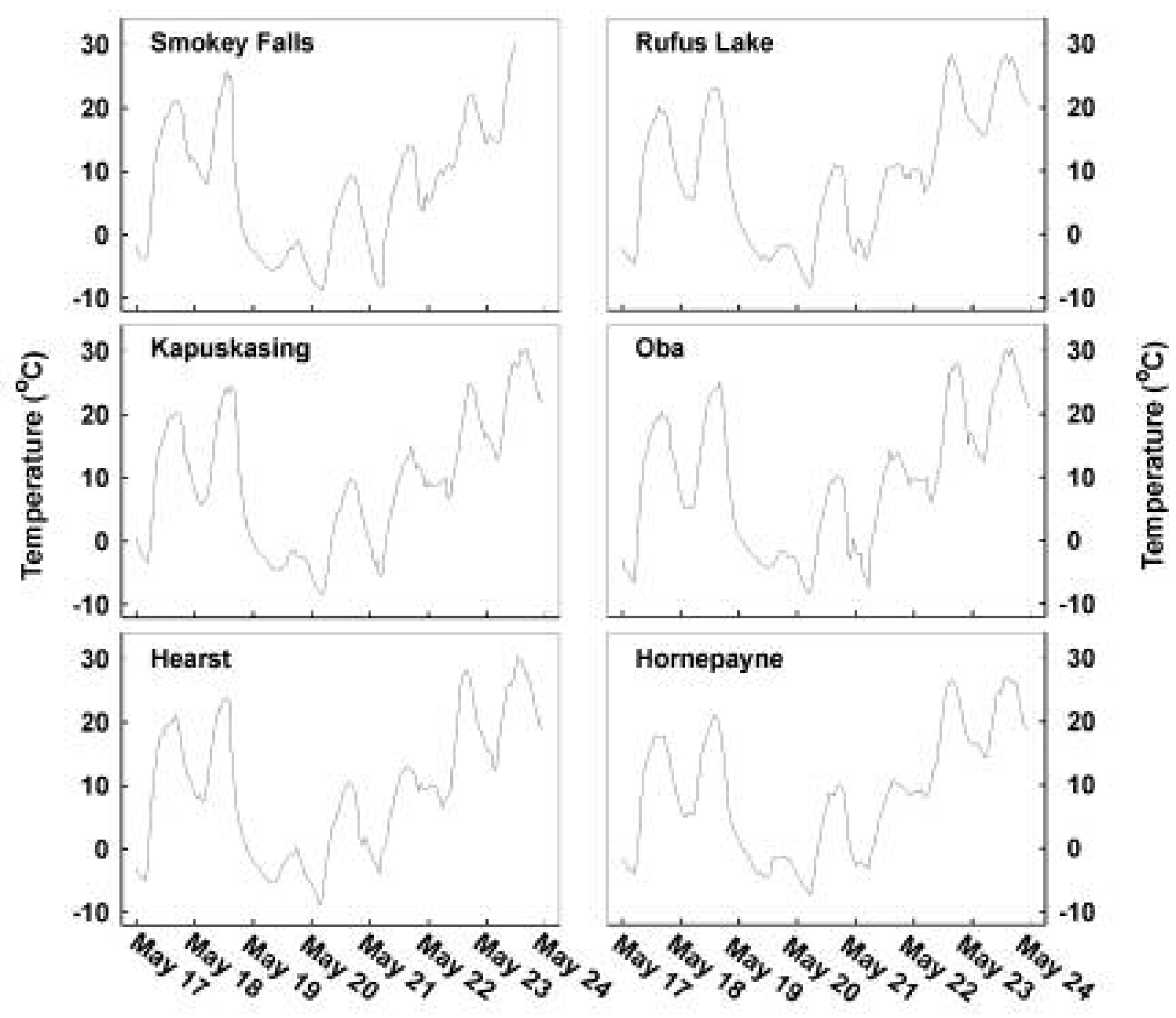

Fig. 6. Hourly air temperatures for May 17-23, 2007 from OMNR fire weather stations at Smokey Falls, Kapuskasing, Hearst, Rufus Lake, Oba, and Hornepayne in the areas of reported conifer damage. 

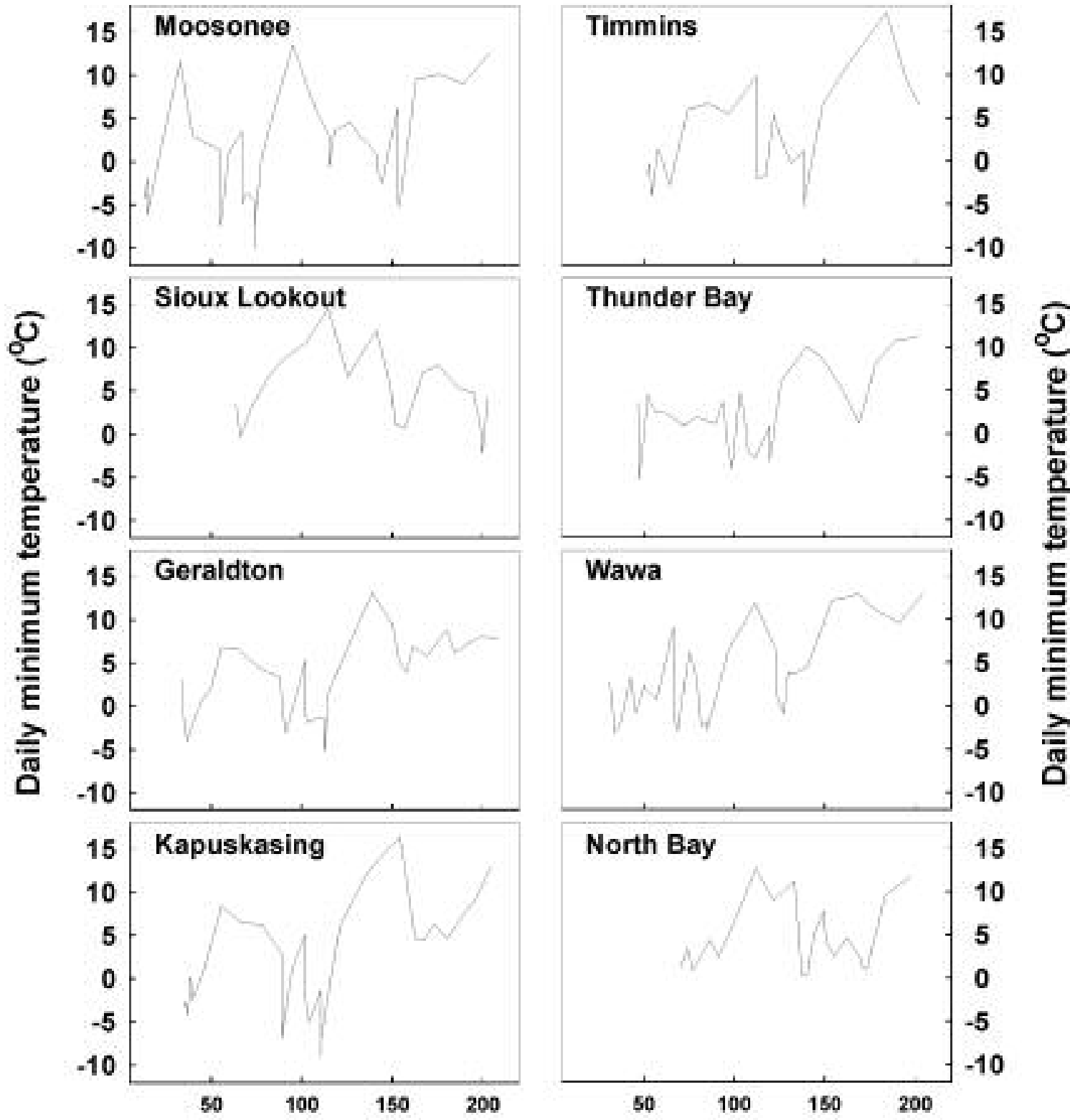

Cumulative growing degree days

Fig. 7. The relationships between cumulative growing degree days and daily minimum temperatures in spring 2007 for selected weather stations in Northern Ontario.

nal buds started to swell. The repeated freeze-thaw over several days (Fig. 6; Levitt 1980) and strong post-freezing solar radiation (Lundmark and Hällgren 1987, Dang et al. 1992) may have caused even more damage; the needles in the lower crown are generally more shade tolerant than those in the upper crown and therefore may be more susceptible to freezing damage, as observed on black spruce by Lamontagne et al. (1998). Microclimatic extremes generally decrease with overstory canopy cover (Man and Lieffers 1999, Krasowski and
Simpson 2001) and tree height (Oke 1987, Stathers 1989), which may also explain reduced damage in the understory and overstory trees. In addition, bud phenology of mature trees may differ from that of small trees due to a vertical gradient of microclimatic conditions (Oke 1987, Stathers 1989). Damage was not noticed or reported on hardwood trees and shrubs; however, hardwood trees (particularly aspen) could have had damage to breaking buds (Parry et al. 1997), but reflushed later in the season. 
Is the Damage Attributable to Climate Change?

We are interested in whether the damage we observed in 2007 is merely random or a part of long-term trend linking to climate change. Table 3 summarizes the incidence of freezing temperatures in spring and average dates of critical GDDs at Kapuskasing from 1918 to 2007. The frequency of freezing temperatures (years with 1 or more freezing nights and average freezing nights per year) from May 16 to June 15 has remained stable for 90 years (Table 3). However, freezing temperatures during budbreak and shoot elongation (between GDD 100 and June 15) have increased since 1980, associated with rising temperatures in the spring (Fig. 8) and, therefore, earlier budbreak. During 1981 to 2007, average dates for the 2 critical GDDs, 100 and 160 , were about 5 days earlier than those during 1918 to 1950 (Table 3). In fact, 2007 was the first year in the 90-year meteorological record at Kapuskasing with daily minimum temperatures of $-8^{\circ} \mathrm{C}$ or colder after cumulative GDD reached 100 .

Contrary to Colombo's (1998) projections for the boreal forest region in Canada, earlier budbreak with climatic warming would likely be associated with increased frost risk at Kapuskasing. In Table 4, individual years from 1918 to 2007 are grouped by estimated Julian day of budbreak (EDB) for 100 GDD into early (EDB < 140, averaged 134), mid (140 $\leq$ $\mathrm{EDB}<150$, averaged 144), and late $(\mathrm{EDB} \geq 150$, averaged 154) budbreak date. The probability of freezing temperatures during budbreak in a given year more than doubles when mean Julian day of budbreak shifts from 144 to 134. If this trend holds into the future, frost damage during budbreak will likely increase greatly in frequency and possibly severity with the advance of budbreak projected for climate change (Cannell and Smith 1986, Colombo 1998).

The observed needle and bud damage, occurrence of cold nights, thermal time requirements for budbreak and cold hardiness of conifers, and historical weather data at Kapuskasing tend to support the hypothesis that climatic warming increases the risk of frost damage by hastening dehardening in spring and increasing tree's vulnerability to subsequent cold periods (Cannell 1985, Hänninen 1991). Historical weather data for Kapuskasing did not indicate much change in frost frequency and severity over the period during which budbreak would occur (mid-May to mid-June). Instead, the probability of potentially damaging freezing temperatures during budbreak have increased with the increase of mean temperatures in spring and the subsequent advance of budbreak, which contradicts the hypothesis that projected warming will be uniform (Cannell and Smith 1986, Kramer 1994, Linkosalo et al. 2000).

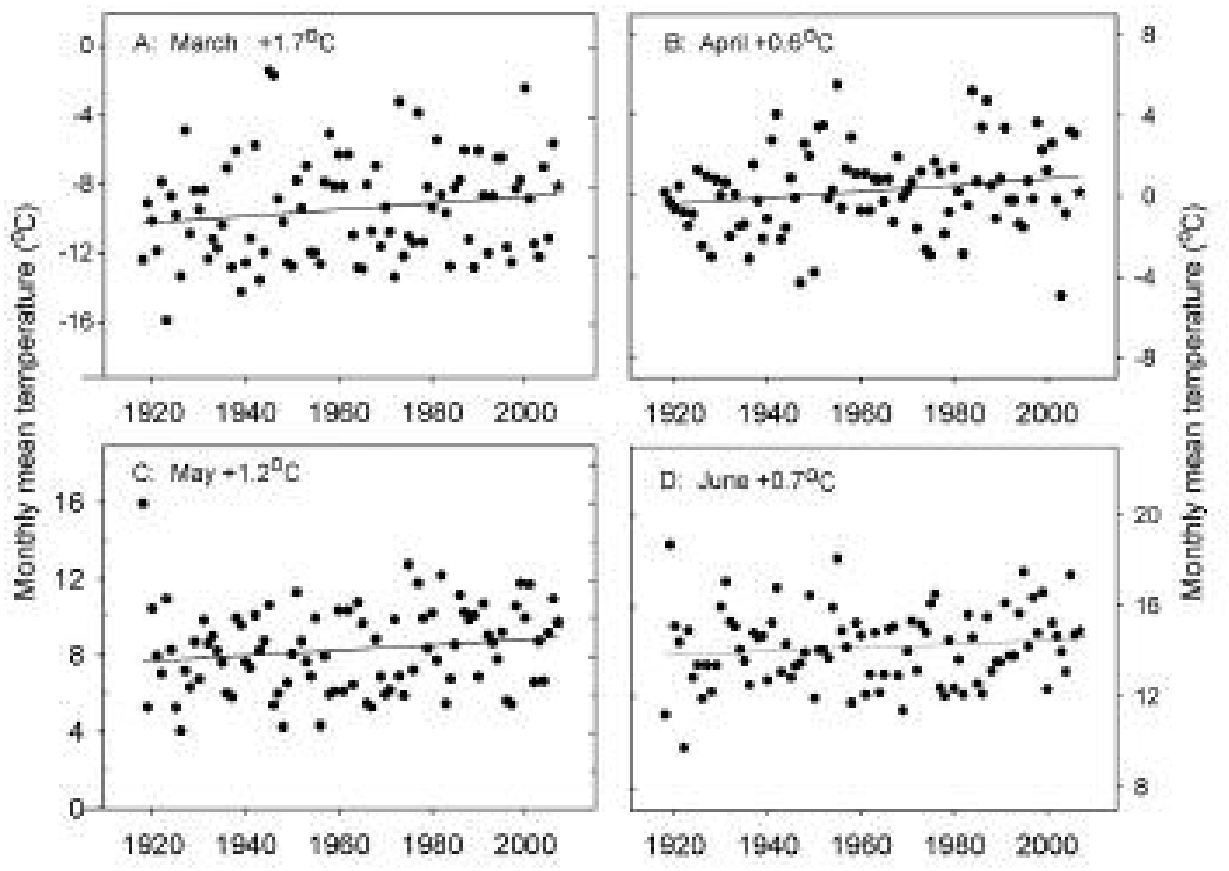

Fig. 8. Monthly mean temperatures in spring and fitted regression lines from March (A), April (B), May (C), to June (D) at Kapuskasing from 1918 to 2007. Overall increases of mean temperatures in 90 years $\left(+{ }^{\circ} \mathrm{C}\right)$ and 2007 data (in stars) are highlighted.

Although some recent modelling exercises have downplayed the possibility of increased frost damage with climate change in boreal conditions (Hänninen 1995, Repo et al. 1996, Hänninen et al. 2001, Colombo 1998), our results show that the risk of frost damage could be increasing at least in some areas. Further study is needed to evaluate the impacts of such widespread spring frost on tree growth and mortality, as well as ecological and economic values.

Table 4. Probability of freezing temperatures by estimated Julian day of budbreak (EDB) for 100 growing degree days at Kapuskasing from 1918 to 2007

\begin{tabular}{lccc}
\hline & $\begin{array}{c}\text { Early } \\
\text { budbreak } \\
(\text { EDB }<\mathbf{1 4 0})\end{array}$ & $\begin{array}{c}\text { Mid } \\
\text { budbreak } \\
(\mathbf{1 4 0} \leq \text { EDB } \\
<\mathbf{1 5 0})\end{array}$ & $\begin{array}{c}\text { Late } \\
\text { budbreak } \\
(\text { EDB } \geq \mathbf{1 5 0})\end{array}$ \\
\hline$\leq 0^{\circ} \mathrm{C}$ & 0.96 & 0.92 & 0.52 \\
$\leq-2.5^{\circ} \mathrm{C}$ & 0.78 & 0.37 & 0.04 \\
$\leq-4^{\circ} \mathrm{C}$ & 0.33 & 0.13 & 0.00 \\
$\leq-6^{\circ} \mathrm{C}$ & 0.15 & 0.05 & 0.00 \\
$\leq-8^{\circ} \mathrm{C}$ & 0.04 & 0.00 & 0.00 \\
Years in category & 27 & 38 & 25 \\
\hline
\end{tabular}


Implications for Forest Management and Research Although damage in the Hearst-Kapuskasing area in 2007 was widespread, we do not expect it to cause lasting problems. We observed that the buds on most affected trees flushed normally in 2007 and that new growth was generally not affected. While needle loss may not cause extensive mortality, especially among large trees, their growth may slow, in turn reducing their vigour and ability to resist stresses such as drought and pests (Bryant et al. 1983).

Long-term weather trends at Kapuskasing suggest that the risk of severe spring frost damage has increased since 1980 due to earlier budbreak. Spring frost damage in a boreal climate, typically occurring at a small scale, is common on newly flushed tissues of small seedlings, due to their high sensitivity (Lester et al. 1977, Dang et al. 1992, Timmis et al. 1994) but rarely on mature needles, especially prior to budbreak. Such pre-budbreak frosts are more severe than post-budbreak ones and can affect young conifers of different sizes and species over large areas. Conifers, traditionally considered frost-resistant due to their late budbreak (Sims et al. 1990), may become vulnerable as the climatic warming progresses.

Forest managers may need to consider the possibility of increasing frost damage in the spring due to warming temperatures and therefore earlier budbreak with climate change (Cannell 1985). One adaptation strategy would be to increase use of shelterwood silviculture to protect young conifers from frost (Smith 1997). Environmental conditions under tree canopies are less extreme, with fewer and less-cold freezing nights as well as cooler temperatures and lower light intensity during the day (Lundmark and Hällgren 1987, Man and Lieffers 1999, Krasowski and Simpson 2001). As shown in Table 3, most frosts are only a few degrees below freezing and can be effectively ameliorated under a forest canopy (Man and Lieffers 1999). This strategy would be suitable for shade-tolerant conifers such as white spruce, balsam fir, white pine, and black spruce but less so for shade-intolerant species such as larch and jack pine.

Researchers should consider climate variability and frost risk when predicting population response and species distribution under climate change (Hamann and Wang 2006, Wang et al. 2006). This may require novel approaches to seed source selection when planting conifers. One such approach would be to move seedlings along a north-south gradient of seed sources, providing more variability in dates of budset and budbreak and therefore reducing risk of widespread frost damage (Aitken and Hannerz 2001, Søgaard et al. 2008). The relatively large within-provenance/population variation in budbreak (O'Reilly and Parker 1982) will also allow identification of late-flushing genotypes that are less susceptible to late spring frost (Slaney et al. 2007, Søgaard et al. 2008). To better understand the risk of frost damage with climate change, research is needed to evaluate climatic variability with warming temperatures and at the same time to examine cold hardiness of boreal conifers, especially during hardening and dehardening, and influences of elevated temperatures and $\mathrm{CO}_{2}$. We also need to quantify genetic variation in bud phenology among and within provenances/populations, which will help facilitate seed transfer and sustain boreal forests under changing climate.

\section{Acknowledgements}

We thank Joshua Breau, Pat Burrough, Véronique Falardeau, Stephen Foley, Nicolas Lizotte, Lauren Quist, Richard Wilson, Cory Wiseman, Nicole Woolnough, and Steve Colombo of the Ontario Ministry of Natural Resources (OMNR); Brad Ekstrom and George Graham of Hearst Forest Management; Jeff Leach and Chad Mcquade of Tembec-Spruce Falls Inc.; and private consultant Harri Liljalehto for their input, discussion, and photographs. We also thank Rob Luik and Helen Zhao (OMNR) for providing fire weather data. Trudy Vaittinen provided technical assistance and Abby Obenchain and 2 anonymous reviewers provided suggestions for improvement of an earlier draft of the manuscript.

\section{References}

Aitken, S.N. and M. Hannerz. 2001. Genecology and gene resources management strategies for conifer cold hardiness. In F.J. Bigras and S.J. Colombo (eds.). Conifer cold hardiness. pp. 23-53. Kluwer Academic Publishers, Dordrecht, Boston.

Berg, E.E. and F.S. Chapin 3rd. 1994. Needle loss as a mechanism of winter drought avoidance in boreal conifers. Can. J. For. Res. 24: 1144-1148.

Bigras, F.J. and A. D’Aoust. 1993. Influence of photoperiod on shoot and root frost tolerance and bud. phenology of white spruce seedlings (Picea glauca). Can. J. For. Res. 23: 219-228.

Bigras, F.J. and C. Hébert. 1996. Freezing temperatures and exposure times during bud break and shoot elongation influence survival and growth of containerized black spruce (Picea mariana) seedlings. Can. J. For. Res. 26: 1481-1489.

Bigras, F.J. and H.A. Margolis. 1997. Shoot and root sensitivity of containerized black spruce, white spruce and jack pine seedlings to late fall freezing. New For. 13: 29-49.

Boyce, R.L. and S.A. Lucero. 1999. Role of roots in winter water relations of Engelmann spruce saplings. Tree Physiol. 19: 893-898.

Bryant, J.P., F.S. Chapin 3rd and D.R. Klein. 1983. Carbon/nutrient balance of boreal plants in relation to vertebrate herbivory. Oikos 40: 357-368.

Cannell, M.G.R. 1985. Analysis of risks of frost damage to forest trees in Britain. In P.M.A. Tigerstedt, P. Puttonen and V. Koski (eds.). Crop physiology of forest trees. pp. 153-166. Helsinki University Press, Helsinki, FI.

Cannell, M.G.R. and R.I. Smith. 1986. Climatic warming, spring budburst and frost damage on trees. J. Appl. Ecol. 23: 177-191.

Colombo, S.J. 1998. Climatic warming and its effect on bud burst and risk of frost damage to white spruce in Canada. For. Chron. 74: 567-577.

Colombo, S.J., S. Zhao and E. Blumwald. 1995. Frost hardiness gradients in shoots and roots of Picea mariana seedlings. Scan. J. For. Res. 10: 32-36.

Curry, J.R. and T.W. Church. 1952. Observations on winter drying of conifers in the Adirondacks. J. For. 50: 114-116.

Dang, Q.L., V.J. Lieffers and R.L. Rothwell. 1992. Effects of summer frosts and subsequent shade on foliage gas exchange in peatland tamarack and black spruce. Can. J. For. Res. 22: 973-979.

Glerum, C. 1973. Annual trends in frost hardiness and electrical impedance for seven coniferous species. Can. J. Plant Sci. 53: 881-889.

Hadley, J.L, A.J. Friedland, G.T. Herrick and R.G. Amundson. 1991. Winter desiccation and solar radiation in relation to red spruce decline in the northern Appalachians. Can. J. For. Res. 21: 269-272.

Hamann, A. and T. Wang. 2006. Potential effects of climate change on ecosystem and tree species distribution in British Columbia. Ecology 87: 2773-2786. 
Hänninen, H. 1991. Does climatic warming increase the risk of frost damage in northern trees? Plant, Cell, and Environ. 14: 449-454.

Hänninen, H. 1995. Effects of climatic change on trees from cool and temperate regions: an ecophysiological approach to modeling of bud burst phenology. Can. J. Bot. 73: 183-199.

Hänninen, H., E. Beuker, Ø. Johnsen, I. Leinonen, M. Murray, L. Sheppard and T. Skrøppa. 2001. Impacts of climate change on cold hardiness of conifers. In F.J. Bigras and S.J. Colombo (eds.). Conifer cold hardiness. pp. 305-333. Kluwer Academic Publishers, Dordrecht, Boston.

Herrick, G.T. and A.J. Friedland. 1991. Winter desiccation and injury of subalpine red spruce. Tree Physiol. 8: 23-36.

Kaufmann, M.R. 1975. Leaf water stress in Engelmann spruce: influence of the root and shoot environment. Plant Physiol. 56: 841-844.

Kim, Y.T., C. Glerum, D.F. Hickie and C.P. Chen. 1997. Effects of cold storage duration on carbohydrate and amino acid concentration, root growth potential, and growth of jack pine and black spruce seedlings. Ont. Min. Nat. Resour., Ont. For. Res. Inst., Sault Ste. Marie, ON. For. Res. Rep. 143.

Kramer, A. 1994. A modelling analysis of the effects of climatic warming on the probability of spring frost damage to tree species in The Netherlands and Germany. Plant, Cell, and Environ. 17: 367-377.

Krasowski, M.J, T. Letchford, A. Caputa and W.A. Bergerud. 1995. Desiccation of white spruce seedlings planted in the southern boreal forest of British Columbia. Water, Air, and Soil Pollut. 82: 133-146.

Krasowski, M.J. and D.G. Simpson. 2001. Frost-related problems in the establishment of coniferous forests. In F.J. Bigras and S.J. Colombo (eds.). Conifer cold hardiness. pp. 253-286. Kluwer Academic Publishers, Dordrecht, Boston.

Lamontagne, M., H. Margolis and F. Bigras. 1998. Photosynthesis of black spruce, jack pine, and trembling aspen after artificially induced frost during the growing season. Can. J. For. Res. 28: 1-12. Lazarus, B.E., P.G. Schaberg, D.H. DeHayes and G.J. Hawley. 2004. Severe red spruce winter injury in 2003 creates unusual ecological event in the northeastern United States. Can. J. For. Res. 34: 1784-1788.

Lazarus, B.E., P.G. Schaberg, G.J. Hawley, and D.H. DeHayes. 2006. landscape-scale spatial patterns of winter injury to red spruce foliage in a year of heavy region-wide injury. Can. J. For. Res. 36: 142-152.

Lester, D.T., S.E. Lindow and C.D. Upper. 1977. Freezing injury and shoot elongation in balsam fir. Can. J. For. Res. 7: 584-588.

Levitt, J. 1980. Response of plants to environmental stresses. Vol. 1. Chilling, freezing and high temperature stresses. $2^{\text {nd }}$ ed. Academic Press, New York, NY.

Lieffers, V.J. and R.L. Rothwell. 1987. Effects of drainage on substrate temperature and phenology of some trees and shrubs in an Alberta peatland. Can. J. For. Res. 17: 97-104.

Linkosalo, T., T.R. Carter, R. Häkkinen and P. Hari. 2000. Predicting spring phenology and frost damage risk of Betula spp. under climatic warming: a comparison of two models. Tree Physiol. 20: $1175-1182$.

Lundmark, T. and J.-E. Hällgren. 1987. Effects of frost on shaded and exposed spruce and pine seedlings planted in the field. Can. J. For. Res. 17: 1197-1201.

Man, R. and V.J. Lieffers. 1997. Seasonal variation of photosynthetic capacities of white spruce (Picea glauca) and jack pine (Pinus banksiana) saplings. Can. J. Bot. 75: 1766-1771.
Man, R. and V.J. Lieffers. 1999. Effects of shelterwood and site preparation on microclimate and establishment of white spruce seedlings in a boreal mixedwood forest. For. Chron. 75: 837-844.

Oke, T.R. 1987. Boundary layer climates. $2^{\text {nd }}$ ed. Methuen and Co., New York, NY.

O'Reilly, C. and W.H. Parker. 1982. Vegetative phenology in a clonal seed orchard of Picea glauca and Picea mariana in northwestern Ontario. Can. J. For. Res. 12: 408-413.

Parry, D., W.J.A. Volney and C.R. Currie. 1997. The relationship between trembling aspen phenology and larval development of the large aspen tortrix. Can. For. Serv., North. For. Cent., Edmonton, AB. Info. Rep. NOR-X 350.

Peart, D.R., M.B. Jones and P.A. Palmiotto. 1991. Winter injury to red spruce at Mount Moosilauke, New Hampshire. Can. J. For. Res. 21: $1380-1389$.

Perkins, T.D. and G.T. Adams. 1995. Rapid freezing induces winter injury symptomatology in red spruce foliage. Tree Physiol. 15: 259-266.

Repo, T., H. Hänninen and S. Kellomäki. 1996. The effects of longterm elevation of air temperature and $\mathrm{CO}_{2}$ on the frost hardiness of Scots pine. Plant Cell Environ. 19: 209-216.

Rowe, J.S. 1972. Forest Regions of Canada. Department of the Environment, Canadian Forestry Service, Ottawa, ON. Publication No. 1300.

Running, S.W. and C.P. Reid. 1980. Soil temperature influences on root resistance of Pinus contorta seedlings. Plant Physiol. 65: 635-640.

Sarvas, R. 1972. Investigations on the annual cycle of development of forest trees. I. Active period. Communicationes Instituti Forestalis Fenniae 76(3). 110 p.

Saxe, H., M.G.R. Cannell, Ø. Johnsen, M.G. Ryan and G. Vourlitis. 2001. Tree and forest functioning in response to global warming. New Phytol. 149: 369-400.

Sims, R.A., H.M. Kershaw and G.M. Wickware. 1990. The autecology of major tree species in the central region of Ontario. Ont. Min. Nat. Resour., Northwest. On. For. Tech. Develop. Unit, Thunder Bay, ON. COFRDA Rep. 3302. NWOFTDU Tech. Rep. 48.

Slaney, M., G. Wallin, J. Medhurst and S. Linder. 2007. Impact of elevated carbon dioxide concentration and temperature on bud burst and shoot growth of boreal Norway spruce. Tree Physiol. 27: 301-312.

Smith, D.M. 1997. The practice of silviculture: applied forest ecology. John Wiley and Sons, Inc., New York, NY.

Søgaard, G., Ø. Johnsen, J. Nilsen and O. Junttila. 2008. Climatic control of bud burst in young seedlings of nine provenances of Norway spruce. Tree Physiol. 28: 311-320.

Stathers, R.J. 1989. Summer frost in young forest plantations. B.C. Min. For., Victoria, B.C. FRDA Rep. 073.

Teskey, R.O., T.M. Hinckley and C.C. Grier. 1984. Temperatureinduced change in the water relations of Abies amabilis (Dougl.) Forbes. Plant Physiol. 74: 77-80.

Timmis, R., J. Flewelling and C. Talbert. 1994. Frost injury prediction model for Douglas-fir seedlings in the Pacific Northwest. Tree Physiol. 14: 855-869.

Van Der Kamp, B.J. and J. Worrall. 1990. An unusual case of winter bud damage in British Columbia interior conifers. Can. J. For. Res. 20: 1640-1647.

Wang, T., A. Hamann, A. Yanchuk, G.A. O’Nell and S.N. Aitken. 2006. Use of response functions in selecting lodgepole pine populations for future climate. Global Change Biol. 12: 2404-2416. 